\title{
BMJ Open Cross-sectional study on the prevalence and predictors of pregnancy among women living in HIV discordant relationships in a rural Rakai cohort, Uganda
}

\author{
Lydia Jacenta Nakiganda, ${ }^{1}$ Anette Agardh, ${ }^{2}$ Benedict Oppong Asamoah ${ }^{2}$
}

To cite: Nakiganda LJ, Agardh A, Asamoah BO. Cross-sectional study on the prevalence and predictors of pregnancy among women living in HIV discordant relationships in a rural Rakal cohort, Uganda. BMJ Open 2018;8:e019818. doi:10.1136/ bmjopen-2017-019818

- Prepublication history for this paper is available online. To view these files, please visit the journal online (http://dx.doi org/10.1136/bmjopen-2017019818).

Received 27 September 2017 Revised 19 March 2018 Accepted 6 April 2018

Check for updates

${ }^{1}$ International Master Programme in Public Health, Faculty of Medicine, Lund University, Lund, Sweden ${ }^{2}$ Social Medicine and Global Health, Department of Clinical Sciences, Malmö, Lund University, Lund, Sweden

Correspondence to Lydia Jacenta Nakiganda; lydianakiganda85@gmail.com

\section{ABSTRACT}

Objectives This study examines the prevalence of pregnancy in serodiscordant couples and identifies predictors associated with pregnancy in rural Rakai, Uganda.

Study design A population-based cross-sectional study that used data from the Rakai Community Cohort Study (RCCS).

Setting and participants We used data from the RCCS survey round 17 (2015-2016), which included 488 women in serodiscordant relationships. This study was conducted in Rakai district, located in south-western Uganda.

Primary outcomes Pregnancy status.

Statistical analysis Multivariable modified Poisson regression using stepwise selection was used to determine characteristics and behaviours associated with pregnancy status.

Results The prevalence of pregnancy was $12 \%$ in women among serodiscordant couples. HIV-negative women in serodiscordant couples had a slightly higher pregnancy prevalence rate (13.6\%) compared with HIV-positive women in serodiscordant couples (11\%). Factors significantly associated with higher prevalence of pregnancy were; younger age 15-24 years (prevalence risk ratio (PRR) $=4.04 ; 95 \% \mathrm{Cl} 1.72$ to 9.50 ), middle age 25-34 years ( $\mathrm{PRR}=2.49 ; 95 \% \mathrm{Cl} 1.05$ to 5.89 ), Christian religion ( $\mathrm{PRR}=2.26 ; 95 \% \mathrm{Cl} 1.41$ to 3.63 ) and inconsistent condom use in the last 12 months (PRR=4.38, 95\% Cl 1.09 to 17.53). Neither HIV status nor HIV status disclosure was significantly associated with risk of getting pregnant. Conclusion Nearly $12 \%$ of women in serodiscordant relationships were pregnant, highlighting the need for integrated services to prevent unintended pregnancies and reduce conceptional related risks for those choosing to conceive. Association with younger age and inconsistent condom use suggests a role for early and continued couple-based conception counselling.

\section{INTRODUCTION}

As the HIV epidemic intensifies in sub-Saharan Africa, the prevalence of HIV infection among women of childbearing age is increasing. ${ }^{1-3}$ In sub-Saharan Africa, $59 \%$ of
Strengths and limitations of this study

- This study was conducted within a large longitudinal cohort that had a high level of retention and quality assurance.

- However, as most data was based on self-reported measures, there could be a potential for recall bias.

- This was a cross-sectional study, which means that causal and temporal relationships are difficult to establish.

- Reporting condom use during the last 12 months may not always accurately characterise a person's overall condom use over a longer period. The frequency of condom use as well as sexual encounters might affect people's ability to accurately remember and report details of sexual encounters.

adults living with HIV are women, the vast majority of whom are of reproductive age. ${ }^{4}$ Uganda has 1.5 million people living with HIV, of whom $57 \%$ are women. ${ }^{5}$ Sexual relationships where one partner is HIV positive and the other sexual partner is HIV negative (serodiscordancy) are common in Africa with almost 5\%-31\% who are married or cohabiting living in these relationships. ${ }^{6-9}$ In Uganda, incidence modelling revealed that $43 \%$ of all new HIV infections were adults living in HIV discordant monogamous relationships. ${ }^{10}$

The majority of the women in discordant relationships face numerous challenges, including desire and commitment to have children ${ }^{11}$ disclosing their HIV status, as well the effects of pregnancy on their own health. ${ }^{12}$ Many women, whether HIV positive or negative, view reproduction as a social and psychological obligation to their partners, ${ }^{12}$ which could be a reason why discordant couples continue to have unprotected sex in order to conceive. ${ }^{13}$ Furthermore, traditional gender 
roles, interpersonal motivation, ${ }^{14}$ societal expectations, partner's influences and HIV stigma are additional factors that might explain why serodiscordant couples practice unprotected sex in order to have children. ${ }^{15}$ Such findings have significant implications since the desire for pregnancy among discordant couples can lead to an increase in high-risk sexual behaviour ${ }^{16}$ with an attendant risk of HIV transmission to the uninfected partner. ${ }^{17} 18$

On the other hand, different options exist for HIV-positive people in discordant relationships to have children including timed intercourse to reduce frequency of intercourse, self-insemination ${ }^{19}$ and improved access to $\mathrm{ART}^{20}$ as the rate of transmission of HIV in serodiscordant couples under conditions of excellent adherence, consistent undetectable blood viral load and continued administration of pre-exposure prophylaxis is very low. However, some of the advanced and efficient reproduction strategies and technologies such as sperm washing and alternative artificial intrauterine insemination that can reduce the risk of horizontal HIV transmission ${ }^{21}$ among discordant couples are either non-affordable or not common in low-income countries. ${ }^{21-23}$

In countries with inadequate health systems such as Uganda with retention levels on ART for women who initiate treatment during pregnancy are progressively declining over time, and only $38 \%$ of infants among those HIV exposed receiving antiretroviral therapy (ARV) for elimination of mother to child transmission (eMTCT) ${ }^{5}$ serodiscordant couples face the risk of possible horizontal and vertical HIV transmission. Therefore, identifying factors associated with pregnancy in discordant couples is relevant, both for gaining insights into HIV transmission dynamics and for designing interventions that meet pregnancy desires and protect reproductive rights while reducing the risk of HIV-1 transmission. In this study, we assessed the prevalence rates of pregnancy in discordant relationships in Rakai, Uganda and identified predictors associated with pregnancy.

\section{METHODS}

\section{Study population}

This cross-sectional study was conducted among serodiscordant couples in Rakai, a rural district located in southwestern Uganda with a population of $518008 .{ }^{24}$ The data for this study was extracted from the Rakai Community Cohort Study (RCCS). RCCS is an open prospective cohort that has been described previously. ${ }^{25} 26$ It has approximately 15000 consenting participants aged 15-49 years who are interviewed in surveys conducted every 12-20 months since 1994, and the overall adult HIV prevalence is $13 \%$. Structured interviews are administered by same sex interviewers, and participants provide interview information and blood samples for HIV serology. Interviews establish information on sociodemographic characteristics, sexual behaviours, health and contextual characteristics. We used data from the survey round 17 (2015-2016).

\section{Eligibility criteria}

Married participants were identified and retrospectively linked to their spouses, including those in polygamous unions. Couples' HIV status was then determined at each visit, and couples were defined as HIV discordant if one member was initially HIV infected and the other uninfected. Those confirmed as discordant and eligible for this study must have reported sex at least once a month and were married or cohabiting at the time of the study. Pregnancy was detected through self-report and a human chorionic gonadotropin urine test for those uncertain about their pregnancy status or whose last menstruation was more than 30 days prior to the interview.

\section{Definition of key variables}

Prevalent pregnancy was the outcome variable and was defined as the proportion of those women in discordant relationships detected as pregnant during the time of the study. Variables that were expected to correlate with pregnancy among discordant couples in the current study were based on previous findings concerning pregnancy predictors among HIV-positive individuals. ${ }^{27-30}$ The variables included were grouped as follows: education level was dichotomised as primary school level/did not attend school and secondary level or higher. Age was grouped into three categories: 18-24 years, 25-34 years and 35-49 years. Religion was dichotomised as Christian and non-Christian. The HIV status of the woman was dichotomised as HIV-1 uninfected and HIV-1 infected. Inconsistent/no condom use was defined on the basis of responses to a question about frequency of condom use during the last 12 months. The response alternatives were dichotomised as consistent condom use for 'always' and inconsistent/no condom use for those who responded that they 'sometimes' or 'never' used condoms. Alcohol use at last sex was dichotomised as 'yes' and 'no'. HIV status disclosure was dichotomised as 'yes' and 'no'. (See table 1 for further details.)

\section{Patient and public involvement}

The RCCS works with the participants within the survey research area to design research questions, ethical guidelines, compensatory time and venues for interviews. Beyond this, there was no further patient and public involvement for this study.

\section{Statistical methods}

The prevalence of pregnancy was determined as the number of women pregnant irrespective of HIV status at the time of study divided by the total number of women in discordant relationships of childbearing age; 15-49 years. Contingency tables were used for bivariate analyses to examine associations between the outcome variable (pregnancy) and the covariates, and $\mathrm{X}^{2}$ tests used for statistical inference. Prevalence risk ratios (PRR) and 95\% CIs were estimated using generalised linear models with family of binomial and log link. Multivariable modified Poisson regression ${ }^{31} 32$ using stepwise selection was 
Table 1 Summary of key variables in this study

\begin{tabular}{|c|c|c|}
\hline Variable & Categorisation & Description/composition \\
\hline \multirow[t]{2}{*}{ Age in years } & $18-24$ & \\
\hline & $25-34$ & \\
\hline \multirow[t]{2}{*}{ Level of education } & Primary & $\leq 7$ years of formal education or no education \\
\hline & Secondary & $>7$ years of formal education \\
\hline Religion & Non-Christians & Moslems and others \\
\hline \multirow[t]{2}{*}{ HIV status } & HIV infected & Woman who tested HIV positive \\
\hline & HIV negative & Women who tested HIV negative \\
\hline Pregnancy status & Pregnant & $\begin{array}{l}\text { Self-reported as pregnant or tested positive after the HCG } \\
\text { urine test }\end{array}$ \\
\hline $\begin{array}{l}\text { Frequency of condom use in the last } \\
12 \text { months }\end{array}$ & Inconsistent & Sometimes, never \\
\hline Alcohol use before sex & Yes/no & Using alcohol at last sex (yes/no) \\
\hline \multirow[t]{2}{*}{ Disclosure of HIV status } & Yes & Marriage partner aware of the HIV status \\
\hline & No & Marriage partner not aware of HIV status \\
\hline
\end{tabular}

HCG, human chorionic gonadotropin.

used while assessing the impact of each variable on the model, using the log likelihood ratio test to estimate adjusted PRRs of characteristics and behaviours associated with pregnancy status. Only variables with $\mathrm{p}<0.05$ in the univariate analyses were included in the multivariate model. Aggregated analyses of all discordant couples were performed irrespective of the HIV status of the women. A further stratified analyses was done with HIV-positive women (whose male sexual partner is negative) and HIV-negative women (whose male partner is positive). All tests of statistical significance were two sided with $\mathrm{p}<0.05 \%$ and $95 \%$ CIs. We used STATA V.13.0 (StataCorp, College Station, Texas, USA) for statistical analyses.

\section{RESULTS}

Table 2 describes the background characteristics of the women in discordant relationships. The median age of participants was 31 years (IQR 26-38 years). The majority of participants were aged 25-34 years $(46.5 \%)$, had primary or no education $(92.6 \%)$ and $74.2 \%$ were non-Christians. Depo Provera was the most commonly reported pregnancy prevention medication, used by $20.3 \%$. Almost $86.7 \%$ were either using condoms inconsistently or not at all in the last 12 months, $48 \%$ had not disclosed their HIV status to their partners and $29.9 \%$ drank alcohol at last sex.

Table 3 shows the prevalence and PRRs of pregnancy among women in discordant relationships. The overall prevalence of pregnancy was 12\% (59/488). HIV-negative women in discordant relationships had a slightly higher pregnancy prevalence rate $(13.6 \%)$ compared with HIV-positive women (11\%). Factors significantly associated with higher prevalence of pregnancy were younger age 15-24 years $(\mathrm{PRR}=4.04 ; 95 \%$ CI 1.72 to 9.50$)$, middle age 25-34 years ( $\mathrm{PRR}=2.49 ; 95 \%$ CI 1.05 to 5.89), Christian religion $(\mathrm{PRR}=2.26$; $95 \% \mathrm{CI} 1.41$ to 3.63$)$ and inconsistent condom use in the last 12 months $(\mathrm{PRR}=4.38$, 95\% CI 1.09 to 17.53$)$. Neither HIV status nor HIV status disclosure was significantly associated with risk of getting pregnant.

Table 4 shows the association between pregnancy status and predictors of pregnancy among women living in discordant relationships obtained through stepwise Poisson regression analyses. In the fully adjusted model (model 3), Christian religion remained a significant predictor of pregnancy $(\mathrm{PRR}=1.71 ; 95 \%$ CI 1.05 to 2.70$)$, whereas middle age (25-34 years; PRR $=2.10$, 95\% CI 0.88 to 4.99 ) and inconsistent condom use in the last 12 months $(\mathrm{PRR}=3.17,95 \% \mathrm{CI} 0.78$ to 12.81$)$ were no longer significant predictors.

Multivariate stepwise Poisson regression models stratified by the HIV status of the women were then used to further examine factors that had significantly predicted pregnancy in the unadjusted analyses (see table 3). The stratified results showed that HIV status was an effect modifier with regard to factors that predicted pregnancy among discordant couples (see tables 5 and 6 ).

In the final model (table 6) for HIV-positive women, both younger age $(\mathrm{PRR}=3.68,95 \% \mathrm{CI} 1.0$ to 12.97$)$ and Christian religion (PRR=2.64, 95\% CI 1.39 to 4.99$)$ were 
Table 2 Baseline characteristics of women in discordant relationships enrolled in a prospective cohort in rural Rakai, Uganda $(n=488)$

\begin{tabular}{|c|c|c|}
\hline Characteristic & Frequency (n) & $\begin{array}{l}\text { Proportion } \\
(\%)\end{array}$ \\
\hline Overall & 488 & 100.0 \\
\hline \multicolumn{3}{|l|}{ HIV status } \\
\hline Positive & 282 & 57.8 \\
\hline Negative & 206 & 42.2 \\
\hline \multicolumn{3}{|l|}{ Age } \\
\hline $15-24$ & 135 & 27.7 \\
\hline 25-34 & 227 & 46.5 \\
\hline $35-49$ & 126 & 25.8 \\
\hline \multicolumn{3}{|l|}{ Level of education } \\
\hline Primary level or lower & 452 & 92.6 \\
\hline Secondary level or upper & 36 & 7.4 \\
\hline \multicolumn{3}{|l|}{ Religion } \\
\hline Christian & 126 & 25.8 \\
\hline Non-Christian & 362 & 74.2 \\
\hline \multicolumn{3}{|l|}{ Number of sexual partners } \\
\hline 1 & 417 & 85.5 \\
\hline$\geq 2$ & 71 & 14.5 \\
\hline
\end{tabular}

Condom use in the last

12 months

\begin{tabular}{|c|c|c|}
\hline Inconsistent & 423 & 86.7 \\
\hline Consistent & 65 & 13.3 \\
\hline \multicolumn{3}{|l|}{ HIV status disclosure } \\
\hline Yes & 254 & 52.0 \\
\hline No & 234 & 48.0 \\
\hline \multicolumn{3}{|c|}{ Alcohol use at last sex } \\
\hline Yes & 147 & 29.9 \\
\hline No & 341 & 69.9 \\
\hline \multicolumn{3}{|c|}{$\begin{array}{l}\text { Most common methods to } \\
\text { prevent pregnancy }\end{array}$} \\
\hline Pills & 9 & 1.8 \\
\hline Condoms & 49 & 10.0 \\
\hline Depo Provera & 99 & 20.3 \\
\hline Implant/Norplant & 30 & 6.1 \\
\hline Calendar & 11 & 2.3 \\
\hline Others or none & 290 & 59.5 \\
\hline
\end{tabular}

significant, whereas for HIV-negative women (table 5), none of the variables remained significant in the final model.

\section{DISCUSSION}

This study found that pregnancy was common among women in discordant relationships with a rate of $12 \%$ and we identified younger age (15-24), middle age (25-34),
Christian religion and inconsistent condom use in the last 12 months as significant predictors of pregnancy among women living in discordant relationships. The pregnancy rate in this cohort is consistent with pregnancy rates in discordant couples in Kenya at $10 \%,{ }^{27}$ in Uganda at $12 \%^{30} 33$ and in South Africa and Zimbabwe at 13.2\%. ${ }^{34}$ Pregnancy is an indicator of unsafe sex, which means women in discordant relationships are at a higher risk of acquiring or transmitting HIV.

Age was a significant predictor of pregnancy in this study, with women at a younger age at increased risk of becoming pregnant compared with older women. Previously, younger age has been correlated with pregnancy after HIV diagnosis, ${ }^{13} 3536$ and thus a woman's age would significantly influence her choice to become pregnant. The results of this study emphasise the importance of quick, accurate information about pregnancy and neonatal transmission among younger women in discordant relationships.

The role of the intimate partners in these relationships should not be underestimated. ART programmes should fully engage and involve partners in the reproductive health decisions especially regarding choice of contraception, desire for another child or any potential consequences that may occur due to unsafe sex. There is a need for an integration of reproductive health services into HIV care programing, and health-related decisions should be made as a couple. Thus, more couple counselling would be recommended.

Consistent condom use in combination with ART, when documentation of viral suppression is not possible, is critical in reducing HIV transmission among heterosexual serodiscordant couples. ${ }^{37}$ Effectiveness of HIV prevention can be increased if ART is given in combination with consistent condom use, as shown in China. ${ }^{38}$ Estimates of the level of protection against HIV transmission from consistent and correct condom use have ranged from $60 \%$ to $96 \%$, making it one of the effective ways of reducing transmissions among discordants. ${ }^{39}$ However, in this study, we observed inconsistent condom use among women in discordant relationships. A possible explanation could be that female partners may not be empowered to advocate for condom use for every sexual act, which is similar to previous studies about condom negotiation. ${ }^{40}$ This finding is consistent with previous studies that have shown low condom use among discordant couples. ${ }^{13} 2041$ Also, the desire for children correlates with low levels of protected sex among HIV-positive persons. ${ }^{42}$ The high rates of inconsistent condom use may indicate the need for additional sexual health education and counselling including condom negotiation skills among female partners in discordant relationships.

The proportion of HIV-positive women in heterosexual serodiscordant relationships in this study was $57 \%$, which shows that women are likely to be the index partner in a discordant couple relationship. These results are consistent with previous studies from five different countries that showed women represented an average $30 \%-50 \%$ of 
Table 3 Prevalence of pregnancy and correlates of pregnancy in a rural cohort in Rakai, Uganda $(n=488)$

\begin{tabular}{|c|c|c|c|c|c|}
\hline Characteristic & Overall & Pregnant (\%) & Not pregnant (\%) & $P$ values & Unadjusted PRR $(95 \% \mathrm{Cl})$ \\
\hline \multicolumn{6}{|l|}{ HIV status } \\
\hline Negative & 206 & $28(13.6)$ & $178(86.4)$ & 0.385 & 0.81 (0.50 to 1.30$)$ \\
\hline Positive & 282 & $31(11.0)$ & $251(89.0)$ & & Ref \\
\hline \multicolumn{6}{|l|}{ Age in years } \\
\hline $15-24$ & 135 & $26(19.3)$ & $109(80.7)$ & 0.001 & 4.04 (1.72 to 9.50$)$ \\
\hline $25-34$ & 227 & 27 (11.9) & $200(88.1)$ & 0.037 & 2.49 (1.05 to 5.89$)$ \\
\hline $35-49$ & 126 & $6(4.8)$ & $120(95.2)$ & & Ref \\
\hline \multicolumn{6}{|l|}{ Educational level } \\
\hline Primary level or lower & 452 & $53(11.7)$ & $399(88.3)$ & 0.373 & 0.70 (0.32 to 1.52$)$ \\
\hline Secondary level or upper & 36 & $6(4.8)$ & $30(83.3)$ & & Ref \\
\hline \multicolumn{6}{|l|}{ Religion } \\
\hline Christian & 126 & $26(20.6)$ & $100(79.4)$ & 0.001 & 2.26 (1.41 to 3.63 ) \\
\hline Non-Christian & 362 & $33(9.1)$ & $329(90.9)$ & & Ref \\
\hline \multicolumn{6}{|l|}{ Number of sexual partners } \\
\hline$\geq 2$ & 71 & $8(11.3)$ & $63(88.7)$ & 0.819 & $0.92(0.45$ to 1.85$)$ \\
\hline 1 & 417 & $51(12.2)$ & $366(87.8)$ & & Ref \\
\hline \multicolumn{6}{|c|}{ Condom use in the last 12 months } \\
\hline Inconsistent & 423 & $57(13.5)$ & $366(86.5)$ & 0.037 & 4.38 (1.09 to 17.53$)$ \\
\hline Consistent & 65 & $2(3.1)$ & $63(96.6)$ & & Ref \\
\hline \multicolumn{6}{|l|}{ HIV status disclosure } \\
\hline Yes & 254 & $30(11.8)$ & $224(88.2)$ & 0.844 & 0.95 (0.59 to 1.53$)$ \\
\hline No & 234 & $29(12.4)$ & $205(87.6)$ & & Ref \\
\hline
\end{tabular}

PRR, prevalence risk ratio.

all discordant couple index cases. ${ }^{40}$ This is at odds with a common assumption that men are the main link to the high-risk groups. ${ }^{13}$ This finding could be explained by some studies in Uganda that have reported similar rates for male to female (12.0 per 100 person-years) and female to male transmission (11.6 per 100 person-years) $)^{20} 41$ and that women are more susceptible biologically to becoming infected than men. In addition, the practice of concurrent

Table 4 Association (adjusted prevalence risk ratios, 95\% $\mathrm{Cl}$ ) between pregnancy status and predictors of pregnancy among 488 women living in discordant relationships in Rakai, Uganda

\begin{tabular}{|c|c|c|c|}
\hline & $\begin{array}{l}\text { Model 1* } \\
\text { PRR }(95 \% \mathrm{Cl})\end{array}$ & $\begin{array}{l}\text { Model 2† } \\
\text { PRR }(95 \% \mathrm{Cl})\end{array}$ & $\begin{array}{l}\text { Model 3¥ } \\
\text { PRR }(95 \% \mathrm{Cl})\end{array}$ \\
\hline \multicolumn{4}{|l|}{ Age in years } \\
\hline $15-24$ & 4.04 (1.72 to 9.50$)$ & 3.24 (1.3 to 7.79 ) & 2.94 (1.20 to 7.19$)$ \\
\hline $25-34$ & 2.49 (1.05 to 5.89$)$ & 2.28 (0.96 to 5.40$)$ & 2.10 (0.88 to 4.99$)$ \\
\hline $35-49$ & Ref & Ref & Ref \\
\hline \multicolumn{4}{|l|}{ Religion } \\
\hline Christian & 2.26 (1.41 to 3.63$)$ & $1.82(1.11$ to 2.97$)$ & 1.71 (1.05 to 2.7$)$ \\
\hline Non-Christian & Ref & Ref & Ref \\
\hline \multicolumn{4}{|c|}{ Condom use in the last 12 months } \\
\hline Inconsistent & 4.38 (1.09 to 17.53$)$ & & 3.17 (0.78 to 12.81$)$ \\
\hline Consistent & Ref & & Ref \\
\hline
\end{tabular}

*Model 1: unadjusted model.

†Model 2: adjusted for age and religion.

¥Model 3: adjusted for age, religion and condom use in the last 12 months.

PRR, prevalence risk ratio. 
Table 5 Multivariate regression analysis of factors associated with pregnancy in discordant couples in which the woman is the HIV-1 negative partner $(n=206)$ in rural Rakai, Uganda

\begin{tabular}{|c|c|c|c|}
\hline Predictors & $\begin{array}{l}\text { Model 1* } \\
\text { PRR (95\% Cl) }\end{array}$ & $\begin{array}{l}\text { Model } 2 \dagger \\
\text { PRR (95\% Cl) }\end{array}$ & $\begin{array}{l}\text { Model 3ł } \\
\text { PRR (95\% Cl) }\end{array}$ \\
\hline \multicolumn{4}{|l|}{ Age in years } \\
\hline $15-24$ & 2.91 (0.85 to 9.94$)$ & 2.68 (0.72 to 9.90$)$ & 2.24 (0.62 to 8.03$)$ \\
\hline $25-34$ & 2.99 (0.90 to 9.98$)$ & 2.96 (0.88 to 9.87 ) & 2.71 (0.82 to 8.92$)$ \\
\hline $35-49$ & Ref & Ref & Ref \\
\hline \multicolumn{4}{|l|}{ Religion } \\
\hline Christian & 1.38 (0.67 to 2.82$)$ & 1.24 (0.56 to 2.75$)$ & 1.14 (0.53 to 2.46$)$ \\
\hline Non-Christian & Ref & Ref & Ref \\
\hline \multicolumn{4}{|c|}{ Condom use in the last 12 months } \\
\hline Inconsistent & 1.85 (1.31 to 2.59$)$ & & 1.48 (0.92 to 2.35$)$ \\
\hline Consistent & Ref & & Ref \\
\hline
\end{tabular}

*Model 1: unadjusted model.

†Model 2: adjusted for age and religion.

$¥$ Model 3: adjusted for age, religion and condom use in the last 12 months.

PRR, prevalence risk ratio.

sexual partnerships, which is common practice in Uganda, is considered to be a critical driver of the AIDS epidemic. ${ }^{42}$ Polygamy, a form of concurrent partnership where a man has multiple cowives, is a common cultural practice and thus polygamous couples are exposed to a larger sexual network which may be one of the reasons for more women being HIV positive in discordant relationships. This study demonstrates continued gendered risks for women in HIV serodiscordant relationships in sub-Saharan Africa. In particular, men with two or more wives are more likely to make decisions about when to have sex or when to use a condom.

Religion was another predictor of pregnancy in HIV-positive women. This is similar to studies done worldwide ${ }^{4344}$ A study in the USA about sexual behaviour attitudes found that women who reported a religious affiliation were less likely to use contraception than non-religious women, ${ }^{45}$ and in a study conducted in a sub-Saharan setting, the importance of religion in the lives of women was a stronger predictor of pregnancy than any other social-cultural factors. ${ }^{46}$ Fears of infection from sexual partners, prevention of unintended pregnancy, risks of potential HIV transmission and abortions may be particular concerns for women in discordant relationships, especially in relation to their religious beliefs. Therefore, healthcare workers should provide appropriate spiritual counselling and support when they encounter such women in their care.

Table 6 Multivariate regression analysis of factors associated with pregnancy in discordant couples in which the woman is the HIV-1 positive partner $(n=282)$ in rural Rakai, Uganda

\begin{tabular}{|c|c|c|c|}
\hline Predictors & $\begin{array}{l}\text { Model 1* } \\
\text { PRR }(95 \% \mathrm{Cl})\end{array}$ & $\begin{array}{l}\text { Model 2† } \\
\text { PRR (95\% Cl) }\end{array}$ & $\begin{array}{l}\text { Model 3ł } \\
\text { PRR }(95 \% \text { CI) }\end{array}$ \\
\hline \multicolumn{4}{|l|}{ Age in years } \\
\hline $25-34$ & 2.18 (0.64 to 7.42$)$ & $1.74(0.51$ to 5.96$)$ & $1.71(0.48$ to 6.0$)$ \\
\hline $35-49$ & ref & ref & ref \\
\hline Christian & $3.42(1.78$ to 6.55$)$ & $2.69(1.42$ to 5.0$)$ & 2.64 (1.39 to 4.99$)$ \\
\hline Non-Christian & ref & 1ref & ref \\
\hline \multicolumn{4}{|c|}{ Condom use in the last 12 months } \\
\hline Inconsistent & $1.98(0.49$ to 7.97$)$ & & 1.19 (0.29 to 4.86$)$ \\
\hline Consistent & ref & ref & ref \\
\hline
\end{tabular}

${ }^{*}$ Model 1: unadjusted model.

†Model 2: adjusted for age and religion.

†Model 3: adjusted for age, religion and condom use in the last 12 months.

PRR, prevalence risk ratio. 
We observed that about $48 \%$ of women in discordant relationships had not disclosed their HIV status to their partners, and in addition, $12.4 \%$ of the women who were pregnant had not disclosed their HIV status to their sexual partners. In a Ugandan context, reproductive issues such as childbearing have a central role in women's social identity. Interviews conducted among HIV-positive pregnant mothers in Uganda highlighted the importance of HIV status disclosure in pregnancy decisions. ${ }^{47}$ Positive women who disclose have been found to encounter reduced pressure to conceive from both their sexual partners and community members. ${ }^{48}$ This study recommends a more prominent role of safe conception in the counselling of discordant couples and more emphasis on the importance of disclosure in discordant relationships. Such a strategy could increase care seeking, improve communication and offer motivation to have better family planning for the future.

In this study, hormonal contraception (oral contraception pill and Depo Provera injection) was more popular (20.3\%) than barrier contraceptives like condoms and implants. This is similar to a study done in Zambia where discordant couples preferred hormonal contraception. ${ }^{49}$ Despite a continued call worldwide about the importance of family planning in discordancy, concerns continue to arise about hormonal contraception increasing a woman's risk to HIV infection or her transmission to her sexual partner. ${ }^{50}$ However, the need clearly exists to make contraception accessible and available to serodiscordant couples who face a dilemma of achieving their fertility desires and managing their risk of HIV infection. This study recommends the need to involve men in family planning decisions, involve them in family planning education and increase family planning counselling, and especially making the discussions between contraceptive use and the HIV infection central.

The major strength of this study was the large longitudinal cohort in which the data were derived that had a high level of retention and quality assurance. Some of the limitations of this study include: the use of cross-sectional data, which limits our ability to derive causal inferences. Second, most data were based on self-reported measures, which are subject to social desirability and recall bias. Third, reporting condom use during the last 12 months may not always accurately characterise a person's overall condom use over a long period. The frequency of condom use as well as recalling sexual encounters might affect people's ability to accurately answer and remember details of sexual encounters.

\section{CONCLUSION}

We found a $12 \%$ pregnancy rate among women in HIV discordant relationships and identified key predictors of pregnancy, thus highlighting the need to develop strategies for making conception safer in discordant relationships. Such studies will require integrated reproductive counselling about reproductive choices and provision of services that reduce unintended pregnancies or conception-related risks especially for women who choose to conceive and, also the need to incorporate fertility-related counselling into HIV treatment services offered at different points.

Contributors LJN conceptualised the study, and designed, analysed and drafted the first version of the manuscript. BOA and AA were involved in the analysis, interpretation and critical review of the manuscript. AA, BOA and LJN were involved in revising the article critically for important intellectual content and approved the final version to be published.

Funding This research received no specific grant from any funding agency in the public, commercial or not-for-profit sectors.

Competing interests None declared.

Patient consent Not required.

Ethics approval The Rakai Community Cohort Study (RCCS) was approved by the Research and Ethics Committee of the Uganda Virus Research Institute, the Uganda National Council of Science and Technology and US-based Western Institutional Review Board.

Provenance and peer review Not commissioned; externally peer reviewed.

Data sharing statement The data sets used for this study are available on request from the Rakai Community Cohort Study database at Rakai Health Sciences Program (www.rhsp.org).

Open Access This is an Open Access article distributed in accordance with the Creative Commons Attribution Non Commercial (CC BY-NC 4.0) license, which permits others to distribute, remix, adapt, build upon this work non-commercially, and license their derivative works on different terms, provided the original work is properly cited and the use is non-commercial. See: http://creativecommons.org/ licenses/by-nc/4.0/

(c) Article author(s) (or their employer(s) unless otherwise stated in the text of the article) 2018. All rights reserved. No commercial use is permitted unless otherwise expressly granted.

\section{REFERENCES}

1. Joint United Nations Programme on HIV/AIDS. Global AIDS update 2016. Geneva: UNAIDS, 2016.

2. Kharsany AB, Karim QA. HIV Infection and AIDS in Sub-Saharan Africa: current status, challenges and opportunities. Open AIDS J 2016;10:34-48.

3. HIV WP. Test and treat all: Progress report 2016. Geneva, Switzerland: World Health Organization, 2016.

4. Joint United Nations Programme on HIV/AIDS (UNAIDS). Prevention gap report 2016. 1, 2016.

5. UNAIDS HIV AND AIDS Uganda country progressive report 2015 , 2016.

6. Lingappa JR, Lambdin B, Bukusi EA, et al. Regional differences in prevalence of HIV-1 discordance in Africa and enrollment of HIV-1 discordant couples into an HIV-1 prevention trial. PLoS One 2008;3:e1411.

7. Lurie MN, Williams BG, Zuma K, et al. Who infects whom? HIV-1 concordance and discordance among migrant and non-migrant couples in South Africa. AIDS 2003;17:2245-52.

8. Ryder RW, Kamenga C, Jingu M, et al. Pregnancy and HIV1 incidence in 178 married couples with discordant HIV-1 serostatus: additional experience at an HIV-1 counselling centre in the Democratic Republic of the Congo. Trop Med Int Health 2000;5:482-7.

9. Carpenter LM, Kamali A, Ruberantwari A, et al. Rates of HIV-1 transmission within marriage in rural Uganda in relation to the HIV sero-status of the partners. AIDS 1999;13:1083-9.

10. Wabwire-Mangen F, Odiit M, Kirungi W, et al. Uganda HIV prevention response and modes of transmission analysis. Kampala: Uganda AIDS Commission (UAC), 2009.

11. Richter DL, Sowell RL, Pluto DM. Factors affecting reproductive decisions of African American women living with HIV. Women Health 2002;36:81-96.

12. Ingram D, Hutchinson SA. Double binds and the reproductive and mothering experiences of HIV-positive women. Qual Health Res 2000;10:117-32. 
13. Beyeza-Kashesya J, Kaharuza F, Mirembe F, et al. The dilemma of safe sex and having children: challenges facing HIV sero-discordant couples in Uganda. Afr Health Sci 2009;9:2-12.

14. Sowell RL, Murdaugh $C L$, Addy $C L$, et al. Factors influencing intent to get pregnant in HIV-infected women living in the southern USA. AIDS Care 2002;14:181-91.

15. Beyeza-Kashesya J, Ekstrom AM, Kaharuza F, et al. My partner wants a child: a cross-sectional study of the determinants of the desire for children among mutually disclosed sero-discordant couples receiving care in Uganda. BMC Public Health 2010;10:247.

16. Brubaker SG, Bukusi EA, Odoyo J, et al. Pregnancy and HIV transmission among HIV-discordant couples in a clinical trial in Kisumu, Kenya. HIV Med 2011;12:316-21.

17. Moodley D, Esterhuizen TM, Pather T, et al. High HIV incidence during pregnancy: compelling reason for repeat HIV testing. AIDS 2009;23:1255-9.

18. Gray RH, Li X, Kigozi G, et al. Increased risk of incident HIV during pregnancy in Rakai, Uganda: a prospective study. Lancet 2005;366:1182-8.

19. Matthews LT, Mukherjee JS. Strategies for harm reduction among HIV-affected couples who want to conceive. AIDS Behav 2009;13(Suppl 1):5-11.

20. Quinn TC, Wawer MJ, Sewankambo N, et al. Viral load and heterosexual transmission of human immunodeficiency virus type 1. N Engl J Med Overseas Ed 2000;342:921-9.

21. Bujan L, Hollander L, Coudert M, et al. Safety and efficacy of sperm washing in HIV-1-serodiscordant couples where the male is infected: results from the European CREAThE network. AIDS 2007;21:1909-14.

22. Oladapo OT, Daniel OJ, Odusoga OL, et al. Fertility desires and intentions of HIV-positive patients at a suburban specialist center. $J$ Natl Med Assoc 2005;97:1672-81.

23. da Silveira Rossi A, Fonsechi-Carvasan GA, Makuch MY, et al. Factors associated with reproductive options in HIV-infected women. Contraception 2005;71:45-50.

24. Uganda Bureau Of Statistics. National population and housing census 2014, 2014.

25. Wawer MJ, Sewankambo NK, Serwadda D, et al. Control of sexually transmitted diseases for AIDS prevention in Uganda: a randomised community trial. Rakai Project Study Group. Lancet 1999;353:525-35.

26. Wawer MJ, Gray RH, Sewankambo NK, et al. A randomized, community trial of intensive sexually transmitted disease control for AIDS prevention, Rakai, Uganda. AIDS 1998;12:1211-25.

27. Guthrie BL, Choi RY, Bosire R, et al. Predicting pregnancy in HIV-1discordant couples. AIDS Behav 2010;14:1066-71.

28. Myer L, Morroni C, Rebe K. Prevalence and determinants of fertility intentions of HIV-infected women and men receiving antiretroviral therapy in South Africa. AIDS Patient Care STDS 2007;21:278-85.

29. Allen S, Meinzen-Derr J, Kautzman M, et al. Sexual behavior of HIV discordant couples after HIV counseling and testing. AIDS 2003;17:733-40.

30. Makumbi FE, Nakigozi G, Reynolds SJ, et al. Associations between HIV antiretroviral therapy and the prevalence and incidence of pregnancy in Rakai, Uganda. AIDS Res Treat 2011;2011:1-10.

31. Zou G. A modified poisson regression approach to prospective studies with binary data. Am J Epidemiol 2004;159:702-6.
32. Zou GY, Donner A. Extension of the modified Poisson regression model to prospective studies with correlated binary data. Stat Methods Med Res 2013;22:661-70.

33. Kaida A, Matthews LT, Kanters S, et al. Incidence and predictors of pregnancy among a cohort of HIV-positive women initiating antiretroviral therapy in Mbarara, Uganda. PLoS One 2013;8:e63411.

34. Reid SE, Dai JY, Wang J, et al. Pregnancy, contraceptive use, and HIV acquisition in HPTN 039: relevance for HIV prevention trials among African women. J Acquir Immune Defic Syndr 2010;53:606-13.

35. Craft SM, Delaney RO, Bautista DT, et al. Pregnancy decisions among women with HIV. AIDS Behav 2007;11:927-35.

36. Massad LS, Springer G, Jacobson L, et al. Pregnancy rates and predictors of conception, miscarriage and abortion in US women with HIV. AIDS 2004;18:281-6.

37. United States Agency for International Development (USAID). Technical issue brief: condom use: how it relates to HIV and STI prevention. Washington DC, 2013.

38. Liu H, Su Y, Zhu L, et al. Effectiveness of ART and condom use for prevention of sexual HIV transmission in serodiscordant couples: a systematic review and meta-analysis. PLoS One 2014;9:e111175.

39. Weller SC, Davis-Beaty K. Cochrane HIV/AIDS Group. Condom effectiveness in reducing heterosexual HIV transmission. Cochrane Database Syst Rev;304.

40. de Walque D. Sero-discordant couples in five African countries: implications for prevention strategies. Popul Dev Rev 2007;33:501-23.

41. Gray RH, Wawer MJ, Brookmeyer R, et al. Probability of HIV-1 transmission per coital act in monogamous, heterosexual, HIV-1discordant couples in Rakai, Uganda. Lancet 2001;357:1149-53.

42. Halperin DT, Epstein H. Concurrent sexual partnerships help to explain Africa's high HIV prevalence: implications for prevention. Lancet 2004:364:4-6.

43. Sowell RL, Misener TR. Decisions to have a baby by HIV-infected women. West J Nurs Res 1997;19:56-70.

44. Raine T, Minnis AM, Padian NS. Determinants of contraceptive method among young women at risk for unintended pregnancy and sexually transmitted infections. Contraception 2003;68:19-25.

45. Romo LF, Berenson AB, Segars A. Sociocultural and religious influences on the normative contraceptive practices of Latino women in the United States. Contraception 2004:69:219-25.

46. Agadjanian V, Yabiku ST. Religious affiliation and fertility in a subsaharan context: dynamic and lifetime perspectives. Popul Res Policy Rev 2014;33:673-91.

47. Kisakye P, Akena WO, Kaye DK. Pregnancy decisions among HIVpositive pregnant women in Mulago Hospital, Uganda. Cult Health Sex 2010;12:445-54.

48. Mark KE, Meinzen-Derr J, Stephenson R, et al. Contraception among HIV concordant and discordant couples in Zambia: a randomized controlled trial. J Womens Health 2007;16:1200-10.

49. Mostad SB, Overbaugh J, DeVange DM, et al. Hormonal contraception, vitamin A deficiency, and other risk factors for shedding of HIV-1 infected cells from the cervix and vagina. Lancet 1997;350:922-7.

50. Morrison CS, Schwingl PJ. Oral contraceptive use and infectivity of HIV-seropositive women. JAMA 1993;270:2298. 
Correction: Cross-sectional study on the prevalence and predictors of pregnancy among women living in HIV discordant relationships in a rural Rakai cohort, Uganda

Nakiganda LJ, Agardh A, Asamoah BO. Cross-sectional study on the prevalence and predictors of pregnancy among women living in HIV discordant relationships in a rural Rakai cohort, Uganda. BMJ Open. 2018;8:e019818. doi: 10.1136/bmjopen-2017-019818.

The published version of this article was missing the acknowledgements section. The authors would like to make readers aware of the following acknowledgement statement: "The authors wish to acknowledge the contributions of the RCCS investigators: Maria Wawer, Ron Gray, Nelson Sewankambo, David Sserwadda, Tom Lutalo, Gertrude Nakigozi, Joseph Kagaayi, Fred Nalugoda and Anthony Ndyanabo for their contribution to the design and implementation of the cohort study and coordination of the field study teams for the collection of the data. The Director, Uganda Virus Research Institute is also acknowledged for his support during the implementation of the RCCS."

Open access This is an open access article distributed in accordance with the Creative Commons Attribution Non Commercial (CC BY-NC 4.0) license, which permits others to distribute, remix, adapt, build upon this work non-commercially, and license their derivative works on different terms, provided the original work is properly cited and the use is non-commercial. See: http://creativecommons.org/licenses/by-nc/4.0/

(c) Article author(s) (or their employer(s) unless otherwise stated in the text of the article) 2018. All rights reserved. No commercial use is permitted unless otherwise expressly granted.

BMJ Open 2018;8:e019818corr1. doi:10.1136/bmjopen-2017-019818corr1

D) Check for updates 